\title{
The Voice of the Child: Are the Procedural Rights of the Child Better Protected in the New Brussels II Regulation?
}

\author{
Slađana Aras Kramar \\ University of Zagreb, Faculty of Law, Zagreb, CROATIA
}

Received: 9 April 2020 • Accepted: 9 July 2020 • Published Online: 25 July 2020

\begin{abstract}
The procedural rights of children in civil court proceedings, and in particular the right of children to be heard in such proceedings, play a significant and growing role in international, European and national context. At the EU level, the growing relevance of the procedural rights of the child has shaped the Brussels II system, originally adopted in the Council Regulation (EC) No 1347/2000 of 29 May 2000, now in the Council Regulation (EC) No 2201/2003 of 27 November 2003 concerning jurisdiction and the recognition and enforcement of judgments in matrimonial matters and the matters of parental responsibility. Recently, the Brussels II system has been the subject of a second recast aimed at better protection of the best interest of the child, including the right to be heard in these matters. The new Regulation II ter will start to apply from 1 August 2022. In this paper, the importance and role of the right of the child to be heard in the Brussels II bis Regulation will be analyzed and discussed, taking into account the jurisprudence of the Court of Justice of the EU. Following that, the impact of the right of the child to be heard on the second recast of the Brussels II System will be evaluated. Last but not least, the paper will try to answer the question of what we have achieved with the new Brussels II ter Regulation in proceedings on parental responsibility from a child rights-based approach.
\end{abstract}

Keywords: right to express an opinion, child, parental responsibility, Brussels II Regulation, recast, procedure.

\section{Introduction}

The procedural rights of children in civil court proceedings, and in particular the right of children to be heard in such proceedings, play a significant and growing role in international, European and national context. The right of the child to be heard is one of the key principles of the 1989 Convention of the Rights of the Child (hereinafter: CRC) (Art. 12 of the CRC; Kilkelly, 2011: 180-182; Committee on the Rights of the Child, 2009: 5, 17-21; Fortin, 2003: 37-38). Article 12 of the CRC addresses the participation of children in proceedings in a way that guaranties to the child who is capable of forming her or his own views, the right to express those views freely in all matters affecting the child, and the right to have her/his views accorded due weight in accordance with the age and maturity of the child. For this purpose, the Paragraph 2 states, in particular, that the child shall be provided the opportunity to be heard in any judicial and administrative proceedings affecting the child, either directly, or through a representative or an appropriate body, in a manner consistent with the procedural rules of national law.

(C) Authors. Terms and conditions of Creative Commons Attribution 4.0 International (CC BY 4.0) apply. Correspondence: Slađana Aras Kramar, Ph.D., Associate Professor, University of Zagreb, Faculty of Law, Department for Civil Procedure, CROATIA. E-mail: saras@pravo.hr. 
The UN Committee on the Rights of the Child has adopted the General Comment No. 12 on the Right of the Child to be Heard. The Committee has stressed that the articles of the CRC should be considered together, but it has itself elevated articles on the right to non-discrimination, the child's best interests, the right to life and development, and the right to be heard among the general principles of the CRC (Committee on the Rights of the Child, 2009: 5, 17; Committee on the Rights of the Child, 2013: 11). In addition, the 1950 European Convention for the Protection of Human Rights and Fundamental Freedoms (hereinafter: ECHR) and the extensive jurisprudence of the European Court of Human Rights in Strasbourg are an increasingly valued source for the development of the procedural standards of participation of children in civil court proceedings (see more in: Stalford, 2012: 36-39; Fortin, 2003: 53 et seq.).

- The right of the child to be heard in court proceedings plays a significant and growing role in international, European and national context.

- At the EU level, the growing relevance of the rights of the child to express her or his views has shaped the Brussels II system.

- The Brussels II system has been the subject of a second recast aimed at better protection of the best interest of the child, including the right to be heard.

- The legal framework and practice of the EU Member States differ regarding the right of the child to express her or his views in court proceedings.

- In the operation of the new Brussels II ter Regulation, the key question will be what exactly is meant by a "genuine and effective" opportunity given to the child to express her or his views.

There have been extensive activities from the Council of Europe and its 1996 European Convention on the Exercise of Children's Rights (hereinafter: ECECR). The ECECR is much more a practical document which aims, in the best interests of children, to grant them procedural rights and to facilitate the exercise of these rights by ensuring that children are, themselves or through other persons or bodies, informed and allowed to participate in proceedings affecting them before a judicial authority, in particular in family proceedings involving the exercise of parental responsibilities (Art. 1, paras. 2 and 3 of the ECECR; see more in: Bainham, 2005: 577-579).

Furthermore, of a significant importance are also the Guidelines of the Committee of Ministers of the Council of Europe on Child-friendly Justice from 2010. Notwithstanding the absence of a legal binding nature, this instrument from the Council of Europe provides guidelines on the right to access to court, the right to be heard, the right to legal counsel and representation, the protection of private and family life, the role of holders of parental responsibilities, professionals and their training, as well as on the multidisciplinary approach (Council of Europe, 2010: 17-23, 26-31). The Guidelines state that child-friendly justice refers to justice systems which guarantee, inter alia, the respect and the effective implementation of all rights of children at the highest attainable level (Council of Europe, 2010: 17).

The right to be heard as a fundamental right of the child and the principle of childfriendly justice strongly influences the functioning of European private international law and procedure. Within the judicial area of the European Union (hereinafter: EU), the focus has shift into the rights of the child, in particular after the Lisbon Treaty (hereinafter: TFEU; Art. 3 of the TFEU) (see Stalford \& Drywood, 2001: 205-206). Alongside with the Member States' international obligation derived from the CRC and the ECHR, it must be stressed the Article 24 of the European Charter of Fundamental Rights (hereinafter: ECFR) which has the same value as the fundamental Treaties (Art. 6, para. 1 of the TFEU). The ECFR grants children the opportunity to express their views freely and assurance that such views shall be taken into consideration on matters which concern them in accordance with their age and maturity, as well as the right to such protection and care as is necessary for their well-being (Art. 24, para. 1. of the ECFR). 
At the EU level, the growing relevance of the procedural rights of the child has shaped the Brussels II system, originally adopted in the Council Regulation (EC) No 1347/2000 of 29 May 2000 on jurisdiction and the recognition and enforcement of judgments in matrimonial matters and in matters of parental responsibility for children of both spouses, now in the Council Regulation (EC) No 2201/2003 of 27 November 2003 concerning jurisdiction and the recognition and enforcement of judgments in matrimonial matters and the matters of parental responsibility, repealing Regulation (EC) No 1347/2000 (hereinafter: Brussels II bis Regulation, BR II bis). The Brussels II bis Regulation, as a cornerstone in family matters in the EU Member States should be interpreted in accordance with the fundamental right of "participation" of children in justice system (see Franzina, 2019: 152; Distefano, 2019: 165; comp. Committee on the Rights of the Child, 2013: 4).

Recently, the Brussels II system has been the subject of a second recast. In 2016, the second recast of the Brussels II system started focusing on the matters of parental responsibility, and aimed at better protection of the best interest of the child, including the right to be heard in these matters (European Commission, 2014: 6 et seq.; European Commission, 2015: 46-56; European Commission, 2016a: 33 et seq). This recast process ended in adopting the Council Regulation (EU) 2019/1111 of 25 June 2019 on jurisdiction, the recognition and enforcement of decisions in matrimonial matters and the matters of parental responsibility, and on international child abduction (hereinafter: Brussels II ter Regulation, BR II ter) which will start to apply from 1 August 2022 (Art. 105 of the BR II ter).

In this paper, the importance and role of the right of the child to be heard in the Brussels II bis Regulation will be analysed and discussed, taking into account the jurisprudence of the Court of Justice of the European Union. Following that, the impact of the right of the child to be heard on the second recast of the Brussels II System will be evaluated. Last but not least, the paper will try to answer the question of what we have achieved with the Brussels II ter Regulation in proceedings on parental responsibility from a child rights-based approach.

\section{The voice of the child in the Brussels II bis Regulation: Overview}

The Brussels II bis Regulation sets out rules on jurisdiction, recognition and enforcement of judgments in matrimonial matters and matters of parental responsibility, including measures for the protection of the child, independently of any link with a matrimonial proceeding (Art. 1, paras. 1 and 2 of the BR II bis).

Notwithstanding of the commitment of the European legislator to respect for the fundamental rights derived from the ECFR (Rec. 33 of the Preamble of the BR II bis), the right of the child to be heard plays a limited role in the Brussels II system. An explicit requirement to hear the child, namely, is connected to child abduction cases in a way that enforcement of any decision to return the child to the country from which she/he has been abducted is not possible if a "capable" child was not given an opportunity to be heard (Arts. 11, para. 2 and 42, para. 2 (a) of the BR II bis). By "capable" child, it seems that the Brussels II bis Regulation acknowledges an assumption that every child is capable to express an opinion, unless this appears inappropriate having regard to her or his age or degree of maturity (arg. ex: Arts. 11, para. 2 and 42, para. 2 (a) of the BR II bis).

A failure to consult with a child may be a ground for non-recognition and enforcement of decision in matters of parental responsibility, as articulated in the Article 23 (b) of the BR II bis. Furthermore, the failure to hear the child plays a role in the process of the issuance of certificates pursuant to the Articles 41, para. 2 (c) and 42, para. 2 (a) of the BR II bis. The decisions on the access rights and those on the child's return are the subject, namely, of the special regime of direct enforceability. For this purpose, the specific certificate must be issued, on which the court of origin 
must declare that the child had an opportunity to be heard, unless a hearing was considered inappropriate having regard to her or his age or degree of maturity (see Arts. 41, para. 2 (c) and 42, para. 2 (a) of the BR II bis.).

Except these provisions in the field of the child's return and the recognition and enforcement of decision in parental responsibility matters, the Brussels II bis Regulation does not provide for any guidelines and methods on how to hear the child by national courts. Of course, the limits of competences of the EU for harmonised measures in the field of procedural rules on the child participation in parental responsibility decisions could be questionable. Indeed, the hearing of the child has an important role in matters of parental responsibility in accordance with the Brussels II bis Regulation, although the Regulation is not intended to modify any national procedural rules applicable, as clearly articulated in the Recital 19 of the Preamble. This has been evidenced in the case of Zarraga, decided by the Court of Justice in December 2010 (C-491/10 PPU).

Mr Zarraga, a Spanish national, and Ms Pelz, a German national, were married in 1998 in Spain. They had a daughter who was born in 2000 whilst the family's habitual residence was in Spain. In 2007, the relationship of Ms Pelz and Mr Zarraga deteriorated and they issued divorce procedure before the Spanish court, with both parties seeking sole rights of custody in respect of the child of the marriage. In 2008, the first instance court in Spain provisionally awarded the right of custody to Mr Zarraga, while Ms Pelz was granted the right of access. Mr Zarraga, namely, was best placed to ensure that the family, school and social environment of the child was maintained, as was reasoned in the judgment. Following that judgment, Andrea went to her father's home (C491/10 PPU: paras. 18, 19).

In 2008, Ms Pelz moved to Germany with her new partner. That summer of 2008, the daughter visited her but failed to return home to her father in Spain. The Spanish court issued a new judgment at the request of the father in the light of mother's breach of the custody and access decision. The court suspended until final judgment the right of access previously granted to Ms Pelz, as well as provisionally ordered the prohibition to the child from leaving Spanish territory in the company of her mother or any member of her mother's family or any person close to her mother (C-491/10 PPU: paras. 20, 21).

In July 2009, the proceedings in matters of custody in respect of the child were continued before the Spanish court who requested a fresh expert report and to hear the child personally. However, neither the child nor her mother attended the hearing on the requested dates. The Spanish court, namely, rejected the mother's application that she and her daughter be permitted to leave Spanish territory freely after the expert report and the hearing. It must be stressed, that the court did not agree to the mothers express request that the child be heard via video conference. In December 2009, the Spanish court awarded the sole right of custody to the father, Mr Zarraga. This decision was appealed by the mother, which included also the request that the child be heard (C-491/10 PPU: paras. 22, 23).

In Germany, there were initiated two sets of proceedings. The first concerned the father's application for the return of the child to Spain, brought on the basis of the 1980 Hague Convention on the Civil Aspects of International Child Abduction. The decision for return was immediately appealed by the mother and set aside by the second instance court. The second instance court in Germany, namely, stated in particular that, when the child was heard by that Court, it had been shown that she was resolutely and categorically opposed to the return requested by her father to return to Spain (C-491/10 PPU: para. 28). Furthermore, the expert concluded following the hearing that the child's opinion should be taken into account in the light of both her age and her maturity (C-491/10 PPU: para. 28).

The second set of proceedings before the German courts was initiated by the issue of a certificate of the Spanish court on the basis of the decision from that Court related to the right of 
custody in respect of the child from December 2009 (Art. 42 of the BR II bis). The mother, namely, objected to the enforcement of that certified judgment, requesting that it not be recognised. The German court upheld this mother's appeal and refused to enforce the certified judgment on the grounds that the Spanish court had not heard the child before issuing its judgment which, it concluded, constituted an infringement of the child's fundamental right to be heard, as stipulated in the Article 24, para. 1 of the ECFR (C-491/10 PPU: para. 32, 34-35).

The German court sought the opinion of the Court of Justice as whether the court of the Member State of enforcement exceptionally itself enjoy a power of review the substance of the case, pursuant to the Article 42 of the Brussels II bis Regulation and the ECFR, in particular the right of the child to be heard (Art. 24, para. 1 of the ECFR), in case where the judgment to be enforced issued in the Member State of origin contains a serious infringement of fundamental rights. Furthermore, whether the court of the Member State of enforcement is obliged to enforce the judgment of the court of the Member State of origin notwithstanding the fact that, according to the case-file, the certificate issued by the court of the Member State of origin in accordance with the Article 42 of the Brussels II bis Regulation contains a declaration which is manifestly inaccurate. The Spanish court confirmed, namely, in the certificate that the court had taken the opinion of the child before issuing the judgment on the right of custody (C-491/10 PPU: para. 37).

The Court of Justice observed that the clear division of jurisdiction between courts of the Member State of origin and those of the Member State of enforcement established by the provisions of the Brussels II bis Regulation lays down on the assumption that those courts respect the obligations which the Regulation imposes on them (C-491/10 PPU: para. 59). Whilst the Brussels II bis Regulation may not be contrary to the ECFR, the provisions of the Article 42 of the BR II bis which give effect to the child's right to be heard, must be interpreted in the light of the Article 24 of the ECFR (C-491/10 PPU: para. 60). In addition, the Court of Justice concluded that the assessment of whether there has been an infringement of fundamental rights is exclusively within the jurisdiction of the courts of the Member States of origin (in Zaragga case, Spanish courts) (C-491/10 PPU: paras. 73, 74). Further to that, a court of the Member State of origin can issue a certificate in accordance with the requirements of the Article 42 of the Brussels II bis Regulation, if the court ensures that proceedings and the judgement to be certified was made with due regard to "the child's right freely to express his or her views and that a genuine and effective opportunity to express those views was offered to the child, taking into account the procedural means of national law," as well as the instruments of international judicial cooperation, in particular the Council Regulation (EC) No 1206/2001 of 28 May 2001 on cooperation between the courts of the Member States in the taking of evidence in civil or commercial matters (C-491/10 PPU: para. 68).

What we have learnt from the Court of Justice ruling in the Zaragga case? First, as the Court of Justice concluded, the Brussels II system operates on the principle of mutual trust between Member States in light that their national legal systems are "capable of providing an equivalent and effective protection of fundamental rights" (C-491/10 PPU: para. 70). Connected with first, the Brussels II system is based on the assumption that the legal systems of the Member States have the equal procedural standards regarding the exercise of the child's right to express an opinion. Even in the case when this assumption is not true and the serious infringement of human rights is obviously, the hands of the court of the Member States of enforcement are tied. Indeed, this is the case with decisions on the access rights and those on the child's return that are the subject of the special regime of direct enforceability. In other matters of parental responsibility, the failure to consult with a child may be a ground for non-recognition and enforcement of a decision issued in another Member State, as articulated in the Article 23 (b) of the BR II bis. Link to this issue is the fact that the Brussels II bis Regulation entirely refers to the national systems and measures of the Member States which give effect to the right of the child to be heard (arg. ex: Rec. 19 of the Preamble of the BR II bis). This approach, of course, can lead to a situation where a 
Member State with stricter procedural rules and standards for the implementation of the right of the child to be heard than the Member State of origin of the decision refuses the recognition and exequatur of such decision on the ground that the hearing of the child does not meet its own standards and practice. Last but not least, when discussing on the right of the child to express her/his views and the ruling of the Court of Justice, it is obvious the conventional tendency of the proper functioning of the internal market, rather than the human right approach to this question (see C-491/10 PPU: para. 70).

3. Impact of the right of the child to express an opinion on the recast of the Brussels II System

At the normative level, the Brussels II ter Regulation has made a step forward in enhancing the exercise of the right of the child to express her or his views. The courts of the Member States exercising their jurisdiction in matters of parental responsibility have an obligation to provide the child who is capable of forming her or his own views with a genuine and effective opportunity to express her or his views, either directly, or through a representative or an appropriate body in accordance with national law and procedure (Art. 21, para. 1 of the BR II ter). For this purpose, the Paragraph 2 states where the court, in accordance with national law and procedure, gives a child an opportunity to express her or his views, the court shall give due weight to the views of the child in accordance with her or his age and maturity. The cited Article 21 of the Brussels II ter Regulation also applies in the procedure for the return of a child in the case of international child abduction (Art. 26 of the BR II ter).

This general rule and obligation of the Brussels II ter Regulation to give a child the opportunity to express an opinion, as well as to give due weight to the views of the child in accordance with her or his age and maturity, now applies in all matters of parental responsibility in the EU perspective. In this European instrument is noticeable the child-oriented tendency and the use of the term "right of the child to express his or her views" rather than the right of the child "to be heard", as well as the acceptance of the normative expression and content of the Article 12 of the CRC.

Link to this general obligation of the Member States, the Brussels II ter Regulation continues to refer to the national legal systems and procedures of the Member States which give effect to the right of the child to be heard. However, following the Court of Justice ruling in the Zaragga case, the Brussels II ter Regulation stipulates that these national procedures of the Member States must guarantee the child "a genuine and effective" opportunity to express her or his views. Alongside to this general provision, there are no examples of methods and procedures that would be considered as "a genuine and effective" opportunity of the child to express her or his views in the context of the Brussels II ter Regulation. However, the Article 21 of the Brussels II ter Regulation should be interpreted in the light of the Article 24 of the ECFR and the Article 12 of the CRC as implemented by national law and procedure of the Member States (arg. ex Rec. 39 of the Preamble of the BR II ter).

Notwithstanding of this commitment of the European legislator to respect for the fundamental rights of the child, the Brussels II ter Regulation leaves the question of methods and procedures of hearing the child to the Member States. In addition, it is expressly stipulated that the hearing of the child "cannot constitute an absolute obligation, but must be assessed taking into account the best interests of the child" (Rec. 39 of the Preamble of the BR II ter). While the Proposal for a recast of the Brussels II System contained a specific obligation of an authority of the Member State of origin to document its consideration regarding the exercise of the right of the child and the assessment of the child's views in the decision (see Art. 20 of the Proposal), there is no such obligation in the adopted Brussels II ter Regulation (arg. ex Art. 21 of the BR II ter). 
Another important fact that must be emphasised is that the abolition of exequatur has been extended to all decisions of parental responsibility falling within the Regulation's scope of application (Rec. 58 of the Preamble of the BR II ter). Not only the decisions on the access rights and on the child's return, but those on the custody rights, child protection orders and placement orders are the subject, namely, of the regime of direct enforceability (arg. ex Art. 34 of the BR II ter). The issue of a certificate on which the court of the Member State of origin must declare that the child was capable of forming her/his own views and that was given a "genuine and effective" opportunity to express those views, has a growing role in this special regime of direct enforceability (see Art. 36 of the BR II ter; pts. 14 and 15 of the Annex III of the BR II ter). Notwithstanding of this obligation to issue a certificate for the purpose of the direct enforcement in another Member State, the court of the Member State of origin has a degree of discretion to decide whether will take an opinion of the child, which methods will be used, as well as how will assess the given opinion of the child (see Recs. 39 and 57 of the Preamble of the BR II ter). To conclude, not only the prescribed methods and procedures of the Member States which give effect to the right of the child to be heard, but also the used methods and the assessment ("due weight") of the views of the child are reserved for the authorities of the Member State of origin.

Nevertheless, in the new Brussels II System, there is a possibility of starting an action for non-recognition of a decision issued in another Member State, except for so-called privileged decisions on the right of access and the return of the child (see Art. 47 and Annexes V and VI of the BR II ter), on the ground that it was issued without the child who is capable of forming her or his own views having been given an opportunity to express her or his views (Art. 39, para. 2 in conjunction with the Art. 21 of the BR II ter). But there are significant restrictions to this control of the court of the Member State of enforcement of the decision. It should not be possible to refuse recognition and enforcement of a decision, namely, on the sole ground that the court of the Member State of origin used a different method to give the child an opportunity to express her or his views than a court in the Member State of recognition would use (Rec. 57 of the Preamble of the BR II ter). In addition, under the Articles 39 and 41 of the BR II ter, the court of the Member State where recognition and enforcement is invoked should not refuse recognition and enforcement of a decision on the sole ground that the child was not given the opportunity to express her or his views, taking into account her or his best interests, if the proceedings only concerned the property of the child and provided that giving such an opportunity was not required in light of the subject matter of the proceedings, or in the case of the existence of serious grounds taking into account, in particular, the urgency of the case. Of course, the term "serious grounds" is a legal standard whose meaning will be interpreted by the court of the Member State of enforcement of the decision. In the Recital 57 of the Preamble of the BR II ter, as an example of the "serious grounds" is described the case where there is an imminent danger for the child's physical and psychological integrity or life and any delay might bear the risk that this danger happens. Therefore, compared to the Brussels II bis Regulation, in the new Regulation the "control" of the Member State of enforcement of the parental responsibility decision should be rather limited.

4. What we have achieved with the Brussels II ter Regulation? A view from the child's perspective

As we have seen in the Zaragga case, the Brussels II system operates on the assumption that the legal systems of the Member States have the equal procedural standards regarding the exercise of the child's right to express an opinion. This assumption is even more enhanced in the new Brussels II ter Regulation. Not only the decisions on the access rights and on the child's return, but those on the custody rights, child protection orders and placement orders are the subject, namely, of the regime of direct enforceability. Link to this fact, in the new regime, the use of the prescribed methods and procedures which give a genuine and effective opportunity 
to the child to express her or his views, as well as the views expressed by the child, are the subject of the assessment of the court of the Member State of origin. Therefore, in principle, there will be no longer a possibility for a Member State of enforcement to refuse recognition and enforcement of a decision on the sole ground that the hearing of the child does not meet its own standards and practice (of the Member State of enforcement), if it can be assumed that the concrete opportunity given to the child in the Member State of origin was "genuine and effective".

Despite the UN General Comment No. 12 on the Right of the Child to be Heard and the commitment of the Committee on the Rights of the Child to develop the standards that must be met when children are heard in judicial proceedings, the normative framework and practice of the EU Member States differ on the questions how to hear the child and how to weight her or his views. Furthermore, it seems that the manner of hearing the child in judicial proceedings is much more in conformity with the legal tradition of the legal system in question (see Daly \& Rap, 2019: 310).

The legal systems of the EU Member States, namely, have different standards required for exercising of the right of the child to express her or his views. In some Member States, the hearing of the child is made obligatory for the (family) court in certain judicial proceedings (see European Commission, 2015: 48; FRA, 2015: 40). For example, this is the case in Croatia and Slovenia when dealing with the matters of parental responsibility, separately or connected with the divorce procedure (see Kraljić, 2018: 484-486; Aras Kramar \& Milas Klarić, 2017: 254-255). However, the hearing of the child will not take place when there are particularly justified reasons for not doing so that must be explained in the court's decision (e.g. when the child does not want to talk) (see Aras Kramar \& Milas Klarić, 2017: 254-255). In some Member States, the courts have a wide range of discretion in question of hearing the child that is in principle connected with the age and/or maturity of the child (for examples, see European Commission, 2015: 48; FRA, 2017: 40; FRA, 2015: 49-50).

In addition, in some legal systems of the Member States, the legal representative is essential for a genuine and effective participation of the child in judicial proceeding on parental responsibility (for so-called tandem model in common law systems, see FRA, 2017: 41-42; FRA, 2015: 48). On the other hand, in other systems, children are regularly interviewed direct by the judges (for example, Germany, the Netherlands, see Daly \& Rap, 2019: 311-312; also see FRA, 2017: 39-40; FRA, 2015: 42-43 et seq.). Of course, there is also a mixture of both models, where in practice the (family) judge usually operates with a socio-economic report in which the views of the child are transmitted, instead of direct contact between the judges and the child (for example, Croatia, see FRA, 2017: 39-40; FRA, 2015: 42-43 et seq.).

Linked to the representatives of the child, there are controversies about the question of what exactly is being represented; the well-being of the child or the child's wishes (for the discussion, see Daly \& Rap, 2019: 312). There are also no clear guidelines on how to weight ("due weight") the views of children. Daly and Rap (2019: 313) suggestion is to take, in general, the children's autonomy principle when assessing the views of the child, respecting wishes of the child unless "significant harm would likely result".

The recent studies on the children's experience of justice system, conducted by the EU Fundamental Rights Agency, show all problems of the implementation of the right of the child to be heard in judicial proceedings (FRA, 2015, 2017). Despite the widely accepted Article 12 of the $\mathrm{CRC}$, the fact is that the practices of the EU Member States differ on the question of exercising the right of the child to express views. The results of the conducted researches among the several EU Member States show that the judges hear children less often in civil (and family) court proceedings (compared to the criminal court proceedings) (FRA, 2015: 49). This is also the case with the participation of children in the international child abduction matters (com. Stalford, 2012: 116117.). Nevertheless, it is important to emphasise how the children interviewed assess their 
participation in judicial proceeding. Sixty-two per cent of the children interviewed, namely, assessed their participation as important (FRA, 2017: 11).

Furthermore, the conducted researches show some of existing deficiencies of the legal systems and practices of the EU Member States. Most children interviewed do not think they were given appropriate information before the hearing took place, in general to enable them to participate effectively in procedure (FRA, 2017: 11). In addition, children did not always feel sufficiently protected from the professionals. Indeed, they experienced the unfriendly behaviour by some professionals (lawyers, judges) (FRA, 2017: 11). In the Member States, different standards are developed and achieved in practice for the facilities where the child will be heard (see FRA, 2017: 29-33 et seq.; FRA, 2015: 46-47 et seq.), as well as for the person (professional) who will talk with the child (see FRA, 2017: 39-43 et seq.; FRA, 2015: 42-43 et seq.). In addition, there are different standards connected with the education and training of (family) judges and other professionals working with children (see FRA, 2017: 55 et seq.; FRA, 2015: 41 et seq.).

Therefore, in the operation of the Brussels II ter Regulation the key question will be what exactly is meant by a "genuine and effective" opportunity given to the child to express her or his views? As it has been already elaborated in this paper, the legal framework and practice of the EU Member States differ regarding the right of the child to express her or his views in judicial proceedings. In addition, there is a general tendency of "non-hearing" the child in civil (and family) matters (compared to the criminal matters) (FRA, 2015: 49). Pro futuro, the EU activities on the development of minimum common guidelines for the implementation of the child's procedural rights, in particular the right to express views in matters of parental responsibility should be considered and planned.

Further to that, in international child abduction cases, it can be questionable whether the Council Regulation (EC) No 1206/2001 of 28 May 2001 on cooperation between the courts of the Member States in the taking of evidence in civil or commercial matters, is sufficient EU instrument to enhance this kind of international judicial cooperation, or it is time to think about a special regulation in parental responsibility matters which will take into account the specific characteristics of cooperation in these matters, as well as the new technology.

\section{Concluding remarks}

The provisions of the CRC, in particular the Articles 12 (on the right to be heard) and 3 (on the best interest of the child), are the most implemented provisions into the legal systems around the world (see Liefaard \& Sloth-Nielsen, 2017: 1 et seq.). This general tendency is also seen in a European context (comp. Carpaneto, 2019: 267 et seq.; Stalford, 2012: 39-47 et seq.).

As we have seen in the Zaragga case, the European Brussels II system operates on the assumption that the legal systems of the Member States have the equal procedural standards regarding the exercise of the child's right to express an opinion. This assumption is even more enhanced in the new Brussels II ter Regulation. Not only the decisions on the access rights and on the child's return, but those on the custody rights, child protection orders and placement orders are the subject, namely, of the regime of direct enforceability. Link to this fact, in the new regime, the use of the prescribed methods and procedures which give a genuine and effective opportunity to the child to express her or his views, as well as the views expressed by children, are the subject of the assessment of the authorities of the Member State of origin. Therefore, in principle, there will be no longer a possibility for a Member State of enforcement to refuse recognition and enforcement of a decision on the sole ground that the hearing of the child does not meet its own standards and practice (of the Member State of enforcement), if it can be assumed that the concrete opportunity given to the child in the Member State of origin was "genuine and effective". 
Although the development in the EU judicial area, achieved with the Brussels II ter Regulation, is to be welcomed, it seems that a "genuine and effective" participation of children in proceedings of parental responsibility is much more in conformity with the procedural rules and practice adopted at the domestic level of the EU Member States. The Member States' international obligation derived from the CRC (and the ECHR, as well as from the ECECR) have achieved some improvements at the domestic level in recent years. Nevertheless, the implementation of these standards for the genuine and effective participation of children in the practice of the justice systems of the EU Member States, in particular the family justice systems has not yet fully occurred. Further to that, the question of whether to hear the child and the manner of hearing the child in judicial proceedings is much more connected with the legal tradition of the Member State in question.

Therefore, in the operation of the Brussels II ter Regulation the key question will be what exactly is meant by a "genuine and effective" opportunity given to the child to express her or his views? Pro futuro, the EU activities on the development of minimum common guidelines for the implementation of the child's procedural rights, in particular the right to express views in matters of parental responsibility should be considered and planned. Of course, a practical guide to the implementation of the Brussels II ter Regulation could be a good start for these common guidelines. Last but not least, in international child abduction cases, it is time to think about a special regulation in the area of judicial cooperation in the taking of evidence which will take into account the specific characteristics of cooperation and hearing the child in these matters, as well as the new technology.

\section{Acknowledgements}

This research did not receive any specific grant from funding agencies in the public commercial, or not-for-profit sectors.

The author declares no competing interests.

\section{References}

Aras Kramar, S., \& Milas Klarić, I. (2017). The main challenges of implementing the procedural rights of the child in the family justice systems of some Southeast European countries. In T. Liefaard \& J. Sloth-Nielsen (Eds.), The United Nations Convention on the Rights of the Child: Taking stock after 25 years and looking ahead (pp. 247-271). Leiden/Boston: Brill/Nijhoff.

Bainham, A. (2005). Children - The modern law, $3^{\text {rd }}$ ed. Bristol: Family Law.

Carpaneto, L. (2019). Impact of the best interests of the child on the Brussels II ter Regulation. In E. Bergamini \& C. Ragni (Eds.), Fundamental rights and best interests of the child in transnational families (pp. 265-285). Cambridge/Antwerp/Chicago: Intersentia.

Committee on the Rights of the Child (2009). General Comment No. 12 (2009) on the Right of the Child to be Heard (CRC/C/GC/12). Geneva: Committee on the Rights of the Child. Retrieved 2 April 2020, from https://www.ohchr.org/EN/HRBodies/CRC/Pages/CRCIndex.aspx.

Committee on the Rights of the Child (2013). General comment No. 14 (2013) on the right of the child to have his or her best interests taken as a primary consideration (art. 3, para. 1) (CRC/C/GC/14). Geneva: Committee on the Rights of the Child. Retrieved 2 April 2020, from https://www2.ohchr.org/English/bodies/crc/docs/GC/CRC C $\quad$ GC 14 ENG.pdf. 
Council of Europe (2010). Guidelines of the Committee of Ministers of the Council of Europe on childfriendly justice. Strasbourg: Council of Europe Publishing. Retrieved 7 April 2020, from https://rm.coe.int/16804b2cf3.

Daly, A., \& Rap, S. (2019). Children's participation in the justice system. In U. Kilkelly \& T. Liefaard (Eds.), International human rights of children (pp. 299-319). Singapore: Springer.

Distefano, M. (2019). The best interests of the child principle at the intersection of private international law and human rights. In E. Bergamini \& C. Ragni (Eds.), Fundamental rights and best interests of the child in transnational families (pp. 157-170). Cambridge/Antwerp/Chicago: Intersentia.

European Commission (2014). Report from the Commission to the European Parliament, the Council and the European Economic and Social Committee on the application of Council Regulation (EC) No 2201/2003 concerning jurisdiction and the recognition and enforcement of judgments in matrimonial matters and the matters of parental responsibility, repealing Regulation (EC) No 1347/200o, COM(2014) 225 final. Brussels: European Commission. Retrieved 2 April 2020, from https://eur-lex.europa.eu/legal-content/EN/TXT/?uri=COM:2014:0225:FIN.

European Commission (2015). Study on the assessment of the Regulation (EC) No 2201/2003 and the policy options for its amendment; Final report; Analytical Annexes. Brussels: European Commission, Directorate-General for Justice and Consumers. Retrieved 2 April 2020, from https://op.europa.eu/en/publication-detail/-/publication/924728ec-9148-11e8-8bc1o1aa75ed71a1.

European Commission (2016a). Commission staff working document, Impact assessment, Accompanying the document - Proposal for a Council Regulation on jurisdiction, the recognition and enforcement of decision in matrimonial matters and the matters of parental responsibility, and on international child abduction (recast), SWD(2016) 207 final. Brussels: European Commission. Retrieved 2 April 2020, from http://eur-lex.europa.eu/legalcontent/EN/TXT/PDF/?uri=CELEX:52016SC0207\&from=EN.

European Commission (2016b). Proposal for a Council Regulation on jurisdiction, the recognition and enforcement of decision in matrimonial matters and the matters of parental responsibility, and on international child abduction (recast), $\operatorname{COM(2016)} 411$ final. Brussels: European Commission. $\quad$ Retrieved 8 April 2020, from https://ec.europa.eu/transparency/regdoc/rep/1/2016/EN/1-2016-411-EN-F1-1.PDF.

Fortin, J. (2003). Children's rights and the developing law. London: LexisNexis.

FRA - European Union Agency for Fundamental Rights (2015). Child-friendly justice. Perspectives and experiences of professionals on children's participation in civil and criminal judicial proceedings in 10 EU Member States. Luxembourg: Publications Office of the European Union.

FRA - European Union Agency for Fundamental Rights (2017). Child-friendly justice. Perspectives and experiences of children involved in judicial proceedings as victims, witnesses or parties in nine EU Member States. Luxembourg: Publications Office of the European Union.

Franzina, P. (2019). The place of human rights in the private international law of the Union in family matters. In E. Bergamini \& C. Ragni (Eds.), Fundamental rights and best interests of the child in transnational families (pp. 141-155). Cambridge/Antwerp/Chicago: Intersentia.

Kilkelly, U. (2011). Using the Convention on the Rights of the Child in law and policy: Two ways to improve compliance. In A. Invernizzi \& J. Williams (Eds.), The human rights of children. From visions to implementation (pp. 179-197). Farnham/Burlington: Ashgate.

Kraljić, S. (2018). Družinski zakonik s komentarjem in podrobnim pojasnili [Family Code with commentary and detailed explanations]. Maribor: Poslovna založba MB, založništvo d.o.o.

Liefaard, T., \& Sloth-Nielsen, J. (2017). 25 Years CRC: Reflecting on successes, failures and the future. In T. Liefaard \& J. Sloth-Nielsen (Eds.), The United Nations Convention on the Rights of the Child: Taking stock after 25 years and looking ahead (pp. 1-13). Leiden/Boston: Brill/Nijhoff.

Stalford, H. (2012). Children and the European Union. Rights, welfare and accountability. Oxford/Portland: Hart Publishing. 
Stalford, H., \& Drywood, E. (2001). Using the CRC to inform EU Law and policy-making. In A. Invernizzi \& J. Williams (Eds.), The human rights of children. From visions to implementation (pp. 199218). Farnham/Burlington: Ashgate.

Council of Europe, (European) Convention for the Protection of Human Rights and Fundamental Freedoms, 4 November 1950. Retrieved 7 April 2020, from https://www.echr.coe.int/Pages/home.aspx?p=basictexts\&c=.

Council of Europe, European Convention on the Exercise of Children's Rights, 25 January 1996, ETS No. 160. Retrieved 7 April 2020, from https://www.coe.int/en/web/conventions/full-list//conventions/treaty/160.

European Union, Charter of Fundamental Rights of the European Union, Official Journal of the EU 2012, C 326, pp. 391-407. Retrieved 8 April 2020, from https://eur-lex.europa.eu/legalcontent/EN/TXT/PDF/?uri=CELEX:12012P/TXT\&from=EN.

European Union, Consolidated version of the Treaty on the Functioning of the European Union, Official Journal of the EU 2012, C 326, pp. 47-199. Retrieved 8 April 2020, from http://eurlex.europa.eu/legal-content/EN/TXT/PDF/?uri=OJ:C:2012:326:FULL\&from=EN.

European Union, Council Regulation (EC) No 1206/2001 of 28 May 2001 on cooperation between the courts of the Member States in the taking of evidence in civil or commercial matters, Official Journal of the EC 2001, L 174, pp. 1-24. Retrieved 8 April 2020, from https://eur-lex.europa.eu/legalcontent/EN/TXT/PDF/?uri=CELEX:32001R1206\&from=EN.

European Union, Council Regulation (EC) No 1347/2000 of 29 May 2000 on jurisdiction and the recognition and enforcement of judgments in matrimonial matters and in matters of parental responsibility for children of both spouses, Official Journal of the EC 2000, L 160, pp. 19-36. Retrieved 8 April 2020, from https://eur-lex.europa.eu/legalcontent/EN/TXT/PDF/?uri=CELEX:32000R1347\&from=EN.

European Union, Council Regulation (EC) No 2201/2003 of 27 November 2003 concerning jurisdiction and the recognition and enforcement of judgments in matrimonial matters and the matters of parental responsibility, repealing Regulation (EC) No 1347/2000, Official Journal of the EU 2003, L 338, pp. 1-29. Retrieved 8 April 2020, from https://eur-lex.europa.eu/legalcontent/EN/TXT/PDF/?uri=CELEX:32003R2201\&from=EN.

European Union, Council Regulation (EU) 2019/1111 of 25 June 2019 on jurisdiction, the recognition and enforcement of decisions in matrimonial matters and the matters of parental responsibility, and on international child abduction, Official Journal of the EU 2019, L 178, pp. 1-115. Retrieved 8 April 2020, from https://eur-lex.europa.eu/legalcontent/EN/TXT/PDF/?uri=CELEX:32019R1111\&from=EN.

Hague Conference on Private International Law, Convention on the Civil Aspects of International Child Abduction, 25 October 1980. Retrieved 8 April 2020, from https://www.hcch.net/en/instruments/conventions/full-text/?cid=24.

UN General Assembly, UN Convention on the Rights of the Child, 20 November 1989, 44/25. Retrieved 2 April 2020, from https://www.ohchr.org/en/professionalinterest/pages/crc.aspx.

Court of Justice of the EU, C-491/10 PPU, Aguirre Zarraga $v$ Simone Pelz. Retrieved 8 April 2020, from http://curia.europa.eu/juris/liste.jsf?language=en\&num $=\mathrm{C}-491 / 10$. 